\title{
The Extent of Using and Trusting Capital Budgeting Methods in Projects Appraisal in Palestinian Corporations
}

\author{
Ahmad N. H. Anabtawi ${ }^{1}$ \\ ${ }^{1}$ Department of Accounting, Faculty of Administrative and Financial Sciences, Arab American University, \\ Palestine \\ Correspondence: Ahmad N. H Anabtawi, Head of Department of Business Administration, Faculty of \\ Administrative and Financial Sciences. Arab American University, P. O. BOX 240, Jenin-West Bank, Palestine. E- \\ mail: ahmad.anabtawi@aauj.edu.
}

Received: May 6, 2018

doi:10.5539/mas.v12n6p151
Accepted: May 16, $2018 \quad$ Online Published: May 31, 2018

URL: https://doi.org/10.5539/mas.v12n6p151

\begin{abstract}
This research paper aims to find the degree of the use as well as the trust of the Net Present Value (NPV), Payback Period (PBP), Internal Rate of Returns (IRR) and Accounting Rate of Returns (ARR) as a key capital budgeting method. The research conducted on the listed corporations in Palestine which are 48 company. A questionnaire distributed on 77 financial and project/operations managers in these corporations with 67 responds.

The result shows that both discounted and non-discounted cash flows methods are used and trusted by Palestine public corporations. However, on the other hand, the above four methods are volatile in term of use and trust. The most used and trusted capital budgeting method is the Payback period (PBP). This followed by the Net Present Value (NPV). Accounting Rate of Retunes (ARR) becomes third. Thus the least used and trusted method is the Internal Rate of Returns (IRR).
\end{abstract}

Keywords: capital budgeting, net present value (NPV), payback period (PBP), internal rate of returns (IRR), accounting rate of returns (ARR)

\section{Introduction}

The early researches of capital budgeting techniques used in entities, discounted cash flow (DCF) techniques, such as the Internal Rate of Return (IRR) and the Net Present Value (NPV). These methods have gained ground as the main methods for evaluating project appraisal and capital budgeting decisions. Despite of some doubts, the universal applicability of the Net Present Value method, it is generally considered better than the payback method, Accounting Rate of Returns (ARR) and the IRR. Non-discounted cash flows treats all cash flows and inflows same regardless the time it occurs. While discounted cash flows (DCF) methods consider the time value of money when evaluating the projects (Bhimani et al 2008).

In theory, many advantages and disadvantages considered for each method applied in capital budgeting. ARR method is a good method reflected in percentages. However, it is based on accounting profit and difficult to apply on different size profit which is cons. Payback period is a quick and easy method in both calculating and understanding. While it does not reflect the profitability, ignoring the cash flows beyond the payback period. Moreover, it has difficulty in calculating cash flows for long term period of time and ignoring the risk and uncertainty are all disadvantages (Atrill and McLaney 2008)

On the other hand, NPV focuses on the timing relevant to the cash flows and reflects the objectives of the business to increase the shareholders wealth. Finally, the IRR method is difficult to understand especially when the project has unconventional cash flows (Atrill and McLaney 2008).

Capital budgeting decisions focus on the multiple time periods projects. Regardless to the profit or loss, the firm could generate future cash inflows to make the project worthwhile (Bhimani et al 2008). PMI defines a project as "a temporary endeavor undertaken to produce a unique product, service, or result" (Heagey, 2012). Thus capital budgeting has a long-range impact on the firm's performance and it is crucial to the firm's success or failure. As such, capital budgeting decisions have a major effect on the value of the firm and its shareholder's wealth as a whole (Don Dayananda et al. 2002).

Using suitable capital budgeting methods in business organizations indirectly related to enhance level of 
investment. According to Iriqat \& Anabtawi (2016) Palestine should motivate investment conditions. Also Daraghma \& Iriqat (2015) recommended the Palestinian decision makers to create suitable investment climate in order to minimize instability effect of Palestinian political. Therefore the stock exchange considered as an indicator for the investment decisions in every country. Palestine stock exchange is an emergent market that need to be studied in term of capital budgeting.

The importance of this research is to figure out the most reliable method of capital budgeting either the discounting or the non-discounting cash flows methods in a developing country such Palestine. The research examines the ARR, PB period, NPV and IRR. In addition, if there is any different method suggested by the population than the mentioned methods.

The objectives of this research is to measure the degree of the use and the trust of each methods of NPV, PBP, IRR and ARR. This paper structure contains the previous literature related to the topic in next section. The thirds part talks about the methodology. The fourth part talks about the analysis and discussion. Finally, the fifth part is the conclusion.

\section{Literature Review}

Pšunder and Ferlan (2007) link the capital budgeting techniques with education. The result finds that, in spite of that non-educated people prefer to use the non-discounted cash flows methods and vice versa. They consider the non-discounted cash flows techniques are still more popular regardless to the education. On the other hand, many other paper such (Jog and Srivastava, 1995), (Payne et al., 1999), (Arnold and Hatzopoulos, 2000) (Farragher et al., 1999), (Graham and Harvey, 2001) and (Ryan and Ryan, 2002) state that due to the wide use of NPV and IRR, discounted cash flow (DCF) has become the prevailing method of evaluation projects. In addition, Kengathran (2016) finds in the study that all most developed and developing countries inclined to use sophisticated capital budgeting methods along with many capital budgeting tools for incorporating risk and sophisticated discounted rate.

Akalua and Turner (2001) examine in a case study the capital budgeting practice of four companies operating in different industries. The paper finds that despite of the use of discounted cash flows techniques, the companies try to combine new value added management tools, which shows a shift in the capital budgeting techniques. On the other hand Brijlal and Quesada (2009) study the capital budgeting methods used by managers in Western Cape at South Africa. The research finds that the Payback Period (PP) technique was the most popular technique used for capital budgeting decisions. The Net Present Value (NPV) technique follows the Payback closely. Internal Rate of Return (IRR) and Profitability Index (PI) become in the third place of reliability in such decisions. Lastly, Accounting Rate of Return (ARR) reported at the tail of the ranking to be used in capital budgeting by managers.

Ryan and Ryan (2002) study the various capital budgeting techniques to be used by the practice. They find the discounted cash flows methods (NPV and IRR) are most used by the companies in their investment decisions. Taylor, P F D (1994/95) finds in the study that 45\% of investment decisions use ARR. The study evaluates how the companies deal with various evaluation techniques in practice. Graham and Harvey (2001) find that IRR is the most appreciated method, while NPV and IRR are more popular than SPP, DPP, or ARR. Shinoda (2010) studies the Japanese stock exchange in 2008 and 2009 to evaluate the capital budgeting practice in Japan. The research finds that, although managers think of payback periods as an important standard when they consider simple and short-range investment plans they may also use NPV when they consider strategic and long-term investment plans. Arshad (2012) studies the authors' opinion in capital budgeting techniques using Google books. The research finds that $52.50 \%$ authors had the view that NPV is better than IRR while $10 \%$ prefers IRR. While the remaining shows the opinion that NPV is better in mutually exclusive projects.

Lunkes et al (2015) examine the Brazilian port and the Spanish port. The Brazilian port uses only the internal rate of return (IRR) as capital budgeting techniques combined with the random rate to determine the minimum acceptable return, and scenario analysis to assess investment risks. While the Spanish port uses all methods in capital budgeting including PB, IRR and NPV.

Thus, there is a gap between theory and practice. Pšunder (2012) concludes the increase of use of NPV and the drawback in using the IRR method. That because the IRR method leads into an incorrect conclusion in decision making process.

The payback method (PB) is commonly used for appraisal of capital investments in companies despite its deficiencies. In many companies, the payback period is used as a measure of attractiveness of capital investments. Although the use of payback period as a single criterion has decreased over time, its use as a secondary measure has increased over time (Segelod, 1995). On the other hand, Brigham \& Ehrhardt (2005) find if all factors is 
constant, project can recover capital investment in shorter payback period which is better than longer recovery rather than the focus on the profitability of the project.in addition PB method does not take into account the cash flows of the project after its payback period.

In developing countries, many researchers conduct their research to figure out the most useful techniques within the business. Samad and Shaharuddin (2009) studies the capital budgeting in Malaysian businesses finding out that large businesses prefer to use DCFs methods while small tend to use the non-discounted cash flows methods.in addition, Alhaddidi (2016) finds Jordan public companies most rely the discounted cash flows methods regardless to the size or financial performance.

However, many other researcher like Khamees et al (2010) examines the industial sector in Jordan. The paper finds Profitability Index is most used in such sector followed by the payback period. Unlike Shaban et al (2017) who conduct the paper base on industrial sector in Jordan as well. The paper finds the net present value (58\%) followed by the payback period (22\%), IRR (12\%) and the remaining for the Accounting Rate of Returns and the Profitability Index. While El-Daour and Abushaaban (2013) who study the capital budgeting techniques in Gaza Strip finding out the profitability index method is mostly used, followed by IRR method. Nevertheless, the net present value (NPV) is the least commonly used methods in capital budgeting.

\section{Methodology}

\subsection{Population and Sample}

The research paper relies on a questionnaire targets the Palestine Stock Exchange (PSE). The number of listed corporations is 48 (PSE, 2018). The questionnaires distributed on both financial and project/operations managers within these corporations. The number of questionnaires distributed is 77, 67 (87\%) questionnaires returned and 10 is cancelled for unreliability of answers.

On the other hand, the level of significance is based on converting Likert five scales into three levels. The formula used:

Range $=($ Max value- Minimum value $) /$ Number of degrees

Range $=(5-1) / 3=1.33$

Highest level upper value $=5-1.33=3.67$

Lower level upper value $=1+1.33=2.33$

Thus:

Table (1). The Classifications of Degree of Range

\begin{tabular}{lll}
\hline Degree of Range & Upper value & Lowe Value \\
\hline High & 5 & 3.67 \\
Moderate & 3.66 & 2.34 \\
Low & 2.33 & 1 \\
\hline
\end{tabular}

\subsection{Research Hypothesis:}

First alternative hypothesis: The use and trust of the capital budgeting decision methods are significantly correlated to each other.

Second alternative hypothesis: Palestine business is highly uses capital budgeting methods.

H2.1: Palestine business highly uses Net Present Value method.

H2.2: Palestine business highly uses Payback Period method.

H2.3: Palestine business highly uses IRR method.

H2.4: Palestine business highly uses Accounting Rate of Returns method.

Third alternative hypothesis: Palestine business is highly trusts capital budgeting methods.

H3.1: Palestine business highly trusts Net Present Value method.

H3.2: Palestine business highly trusts Payback Period method.

H3.3: Palestine business highly trusts IRR method. 
H3.4: Palestine business highly trusts Accounting Rate of Returns method.

\section{Analysis and Discussion}

\subsection{Descriptive Statistics}

Table (2) shows that the most method used in capital budgeting is the payback period with $71.9 \%$ reflect the very high (more than $90 \%$ ). Net present value is highly (70\%-89\%) used by $64.9 \%$ of the respondents. While $54.4 \%$ of respondents reflect the moderate use (50\%-69\%). The least method in use is the IRR with $66.7 \%$ of respondents say a very low (less 19\%) use. This means that Palestine corporations mostly use the payback period method, followed by the net present value, then the accounting rate of returns. While the IRR method is the least one in term of use by both financial and project/operations managers within Palestinian corporations.

Table (2). Descriptive Statistics of Capital Budgeting Methods Use Level

\begin{tabular}{llllll}
\hline \multirow{2}{*}{$\begin{array}{l}\text { Capital } \\
\text { Methods }\end{array}$} & Budgeting Decision & \multicolumn{2}{l}{ Using level (\%) } & & \\
\cline { 2 - 6 } & Very High & High & Moderate & low & Very low \\
\hline Net Present Value & 24.6 & $\mathbf{6 4 . 9}$ & 7 & 3.5 & $\mathbf{0}$ \\
Pay Back Period & $\mathbf{7 1 . 9}$ & 22.8 & 3.5 & 1.8 & $\mathbf{0}$ \\
Internal Rate of Return & 0 & 7 & 10.5 & 15.8 & $\mathbf{6 6 . 7}$ \\
Accounting Rate of Return & 10.5 & 17.5 & $\mathbf{5 4 . 4}$ & 12.3 & $\mathbf{5 . 3}$ \\
\hline
\end{tabular}

Table (3) explains the trust level of the capital budgeting methods. The result shows $57.9 \%$ very high trust the payback period method. This followed by the NPV method with $64.9 \%$ respondents reflect a high trust of the method. ARR becomes third with a moderate level of trust and IRR is the least with low trust level. This means that Palestine corporations mostly trust the payback period method, followed by the net present value, then the accounting rate of returns. While the IRR method is the least one in term of the trust by both financial and project/operations managers within Palestinian corporations.

Table (3). Descriptive Statistics of Capital Budgeting Methods Trust Level

\begin{tabular}{llllll}
\hline \multirow{2}{*}{$\begin{array}{l}\text { Capital } \\
\text { Methods }\end{array}$} & Budgeting Decision & \multicolumn{2}{l}{ Trust level (\%) } & & \\
\cline { 2 - 6 } & Very High & High & Moderate & low & Very low \\
\hline Net Present Value & 24.6 & $\mathbf{6 4 . 9}$ & 10.5 & 0 & $\mathbf{0}$ \\
Pay Back Period & $\mathbf{5 7 . 9}$ & 31.6 & 10.5 & 0 & $\mathbf{0}$ \\
Internal Rate of Return & 5.3 & 12.3 & 29.8 & 12.3 & $\mathbf{4 0 . 4}$ \\
Accounting Rate of Return & 7 & 19.3 & $\mathbf{5 6 . 1}$ & 15.8 & $\mathbf{1 . 8}$ \\
\hline
\end{tabular}

\subsection{Testing Hypothesis}

First alternative hypothesis: The use and trust of the capital budgeting decision methods are significantly correlated to each other.

Table (4) represents the Person correlation coefficient between use and trust of the capital budgeting decision methods (NPV, PB, IRR and ARR). Findings in table (4) below indicate a significant positive relationship between the use and trust for NPV, IRR, and ARR $(\mathrm{r}=.327, \mathrm{p}<0.013, \mathrm{r}=.271, \mathrm{p}<0.041, \mathrm{r}=.319, \mathrm{p}<0.016)$ respectively. Thus, the results support the first alternative hypothesis for each of NPV, IRR and ARR. In addition, the findings show that the use and trust of payback period are not empirically associated $(r=.223, p<0.095)$

Table (4). Correlation Matrix among Use and Trust in Capital Budgeting Decision Methods

\begin{tabular}{llll}
\hline Capital Budgeting Decision Methods & Coefficient & P-value & Result \\
\hline Net Present Value & $\mathbf{0 . 3 2 7}$ & $\mathbf{0 . 0 1 3}$ & Sig. \\
Pay Back Period & 0.223 & 0.095 & Not sig. \\
\hline
\end{tabular}




\begin{tabular}{llll}
\hline Internal Rate of Return & 0.271 & $\mathbf{0 . 0 4 1}$ & Sig. \\
Accounting Rate of Return & 0.319 & $\mathbf{0 . 0 1 6}$ & Sig. \\
\hline
\end{tabular}

\section{Second alternative hypothesis: Palestine business is highly uses capital budgeting methods.}

Table (5) shows that a one sample $t$ test was conducted evaluate whether their mean was significantly different from 3.67 as a cut point. The accepted mean for Palestinian corporations in general. The results represent that net present value, payback period, internal rate of return, and accounting rate of return play a significant role in Palestinian corporations $(\mathrm{t}=4.882, \mathrm{p}$-value $=0.000, \mathrm{t}=11.539, \mathrm{p}$-value $=0.000, \mathrm{t}=-16.725, \mathrm{p}$-value $=0.000$, and $\mathrm{t}=-6.513$, $\mathrm{p}$-value $=0.000)$ respectively .in addition, based on mean values, table(5) shows that the highest mean reflected for the payback period with $(\mathrm{M}=4.65, \mathrm{~S} . \mathrm{D}=0.641)$, that's mean the payback period has the most significant in term of the use of capital budgeting decision methods. This followed by NPV (M=4.11, S.D $=$ $0.673)$. Whereas, ARR has a moderate level of significance with $(\mathrm{M}=2.84, \mathrm{~S} . \mathrm{D}=0.960)$. Finally, IRR method has low level of significance with $(\mathrm{M}=1.58, \mathrm{~S} . \mathrm{D}=0.944)$,

This support the alternative hypothesis above that there is in general a sufficient evidence that capital budgeting decision methods play a significant role in Palestinian corporations. Thus the statistical analysis accepts the H1.1 and H1.2 that the use of payback period and the NPV is significantly high. While, H1.3 is rejected with low use of the IRR method usage by Palestine corporations. Moreover, H1.4 is rejected with a moderate use of the ARR methods use. However, all of the methods mentioned in Table (5) below have a significant role in capital budgeting.

Table (5). The results of second alternative hypothesis

\begin{tabular}{lllllll}
\hline Capital Budgeting Decision Methods & Mean & S.D & D.F & S.E.M & T- Value & Sig. \\
\hline Palestine business highly uses NPV method. & 4.11 & .673 & 56 & .089 & 4.882 & $\mathbf{. 0 0 0}$ \\
Palestine business highly uses PB method. & 4.65 & .641 & 56 & .085 & 11.539 & $\mathbf{. 0 0 0}$ \\
Palestine business highly uses IRR method. & 1.58 & .944 & 56 & .125 & -16.725 & $\mathbf{. 0 0 0}$ \\
Palestine business highly uses AAR method. & 2.84 & .960 & 56 & .127 & -6.513 & $\mathbf{. 0 0 0}$ \\
\hline
\end{tabular}

\section{Third alternative hypothesis: Palestine business is highly trusts capital budgeting methods.}

A one sample $t$ test was conducted evaluate whether their mean was significantly different from 3.67 as a cut point, the accepted mean for Palestinian corporations in general. The results represent that net present value, payback period, internal rate of return, and accounting rate of return play a significant role in Palestinian corporations $(\mathrm{t}=$ 6.116, $\mathrm{p}$-value $=0.000, \mathrm{t}=8.869, \mathrm{p}$-value $=0.000, \mathrm{t}=-8.173, \mathrm{p}$-value $=0.000$, and $\mathrm{t}=-4.799, \mathrm{p}$-value $=0.000$ ) respectively. In addition, based on mean values, table (6) shows that the highest mean reflected for the payback period with $(\mathrm{M}=4.47, \mathrm{~S} . \mathrm{D}=0.684)$. It means the payback period has the most significant in term of the trust of capital budgeting decision methods. This followed by NPV $(\mathrm{M}=4.14, \mathrm{~S} . \mathrm{D}=0.581)$. Whereas, ARR has a moderate level of significance with $(\mathrm{M}=3.14, \mathrm{~S} . \mathrm{D}=0.833)$. Finally, IRR method has low level of significance with $(\mathrm{M}=3.30$, $\mathrm{S} . \mathrm{D}=1.267)$.

This support the alternative hypothesis above that there is in general a sufficient evidence that capital budgeting decision methods play a significant role in Palestinian corporations. Thus the statistical analysis accepts H1.1 and H1.2 that the trust of payback period and the NPV is significantly high. While, H1.3 is rejected with low use of the IRR method trusted by Palestine corporations. Moreover, H1.4 is rejected with a moderate trust of the ARR methods use. On the other hand, all of the methods mentioned in table (6) below have a significant role in capital budgeting.

Table (6). The results of third alternative hypothesis

\begin{tabular}{llllllll}
\hline $\begin{array}{l}\text { Capital } \\
\text { Methods }\end{array}$ & Budgeting Decision & Mean & S.D & D.F & S.E.M & T- Value & Sig. \\
\hline $\begin{array}{l}\text { Palestine business highly trusts } \\
\text { NPV method. }\end{array}$ & 4.14 & .581 & 56 & .091 & 6.116 & $\mathbf{. 0 0 0}$ \\
$\begin{array}{l}\text { Palestine business highly trusts } \\
\text { Pat }\end{array}$ & & & & & & \\
\hline
\end{tabular}




\begin{tabular}{|c|c|c|c|c|c|c|}
\hline \multicolumn{7}{|l|}{ PB method. } \\
\hline Palestine business highly trusts & 2.30 & 1.267 & 56 & .110 & -8.173 & .000 \\
\hline \multicolumn{7}{|l|}{ IRR method. } \\
\hline Palestine business highly trusts & 3.14 & .833 & 56 & .077 & -4.799 & .000 \\
\hline
\end{tabular}

\section{Conclusion}

The research shows that Palestine corporations use and trust the capital budgeting methods. They use and trust both the discounted and the non-discounted cash flows methods. However, the use and trust is differential between the different methods. The use and trust is the most for the payback period method. This result because of the nature of the business and the economy in Palestine. The second method in term of both the use and trust is the NPV method which is a discounted cash flows method. In the third place is the ARR and IRR is the least used and trusted method by the Palestinian corporations. The above result is aligned by many literature mentioned above such as Pšunder (2012), Shinoda (2010), Khamees et al (2010) and Brijlal and Quesada (2009). On the other hand, many of previous literature have an opposite result such Ryan and Ryan (2002), Kengathran (2016), Shaban et al (2017) and El-Daour and Abushaaban (2013).

Eventually, other future research papers could be conducted to figure out the reason making businesses choose a particular method in preference to another. In addition, the development and the shift could happen in the future in using and trust of the capital budgeting methods in the developing countries such Palestine.

\section{References}

Akalu, M. M., \& Turner, R. (2001). The practice of investment appraisal: An Empirical Enquiry? Rotterdam: Erasmus Research Institute of Management (ERIM).

Akalu, M. M., \& Turner, J. R. (2001). Investment Appraisal Process in the Banking \& Finance industry. Working Paper (forth coming).

Alhaddidi, E. (2016). Using Capital Budgets Techniques in Evaluating Investments Projects: Applied Study on Jordanian Industrial Corporations. Research Journal of Finance and Accounting, 7(24), 64-70.

Arnold, G. C., \& Hatzopoulos, P. D. (2000). The theory-practice gap in capital budgeting: evidence from the United Kingdom. Journal of business finance \& Accounting, 27(5-6), 603-626.

Arshad, A. (2012). Net present value is better than internal rate of return. Interdisciplinary Journal of Contemporary Research in Business, 4(8), 211-219.

Atrill, P., \& McLaney, E. (2008). Accounting and Finance for Non-Specialists. Sixth Edition. Prentice Hall, Financial Times.

Bhimani, A., Horngren, C., Dtar, S., \& Foster, G. (2008). Management and Cost Accounting (4th ed.) Prentice Hall, Financial Times.

Brigham, E. F., \& Ehrhardt, M. C. (2005). In Financial Management (11th, International Student ed., p. 347). South-Western Cengage Learning.

Brijlal, P., \& Quesada, L. (2009). The Use of Capital Budgeting Techniques in Businesses: A Perspective from The Western Cape. The Journal of Applied Business Research, 25(4), 37-46. http://dx.doi.org/10.2139/ssrn.1259636.

Daraghma, Z. M. A., \& Iriqat, R. A. M. (2015). Exploring economy dependence in the Middle East using governmental accounting indicators: The case of Palestine, Jordan \& Israel. International Business Research, 9(1), 154. https://doi.org/10.5539/ibr.v9n1p154

Dayananda, D., Irons, R., Harrison, S., Herbon, J., \& Rowland, P. (2002). Capital budgeting: financial appraisal of investment projects. Cambridge University Press.

El-daour, A., \& Abu Shaaban, M. (2013). The Use of Capital Budgeting Techniques in Evaluating Investment Projects: An Applied Study on the Palestinian Corporations Working in Gaza Strip. Journal of Al-Quds Open University for Research and Studies. No. 32- Part (2) - October 2014, 10-50.

Farragher, E. J., Kleiman, R. T., \& Sahu, A. P. (1999). Current capital investment practices. The Engineering Economist, 44(2), 137-150. 
Farragher, E. J., Kleiman, R. T., \& Sahu, A. P. (2001). The association between the use of sophisticated capital budgeting practices and corporate performance. The engineering economist, 46(4), 300-311.

Graham, J. R., \& Harvey, C. R. (2001). The theory and practice of corporate finance: Evidence from the field. Journal of financial economics, 60(2-3), 187-243.

Heagney, J. (2012). Fundamentals of Project Management. American Management Association. Fourth Edition. American Management Association.

Iriqat, R. A., \& Anabtawi, A. N. (2016). GDP and Tax Revenues-Causality Relationship in Developing Countries: Evidence from Palestine. International Journal of Economics and Finance, 8(4), 54. https://doi.org/10.5539/ijef.v8n4p54

Jog, V. M., \& Srivastava, A. K. (1995). Capital budgeting practices in corporate Canada. Financial practice and education, 5(2), 37-43.

Kengatharan, L. (2016). Capital budgeting theory and practice: a review and agenda for future research. Applied Economics and Finance, 3(2), 15-38. https://doi.org/10.11114/aef.v3i2.1261.

Khamees, B. A., Al-Fayoumi, N., \& Al-Thuneibat, A. A. (2010). Capital budgeting practices in the Jordanian industrial corporations. International journal of commerce and management, 20(1), 49-63 https://doi.org/10.1108/10569211011025952

Lunkes, R. J., Ripoll-Feliu, V., Giner-Fillol, A., \& da Rosa, F. S. (2015). Capital budgeting practices: A comparative study between a port company in Brazil and in Spain. Journal of Public Administration and Policy Research, 7(3), 39. https://doi.org/10.5897/JPAPR2014.0294

$\begin{array}{llllll}\text { Palestine } & \text { Stock } & \text { Exchange. } & \text { (2018). Retrieved }\end{array}$ http://www.pex.ps/PSEWebSite/AboutPSE.aspx?TabIndex $=0$.

Payne, J. D., Heath, W. C., \& Gale, L. R. (1999). Comparative financial practice in the US and Canada: Capital budgeting and risk assessment techniques. Financial Practice and Education, 9, 16-24.

Pšunder, I. (2012). Use of discounted cash flow methods for evaluation of engineering projects. In Mechanical Engineering. InTech.

Psunder, I., \& Ferlan, N. (2007). Analysis of the knowledge and the use of investment project evaluation methods in the field of mechanical engineering. Strojniski Vestnik-Journal of Mechanical Engineering, 53(9), 569-581.

Ryan, P. A., \& Ryan, G. P. (2002). Capital budgeting practices of the Fortune 1000: how have things changed? Journal of business and management, 8(4), 355.

Samad, F. A., \& Shaharuddin, R. S. (2009). The perception of risk and uncertainty and the usage of capital budgeting techniques: Evidence from public listed firms in Malaysia. Jurnal Pengurusan (UKM Journal of Management), 29.

Segelod E. (1995). Resource Allocation in Divisionalized Groups, Ashgate, Avebury.

Shaban, O. S., Al-Zubi, Z., \& Abdallah, A. A. (2017). The Extent of Using Capital Budgeting Techniques in Evaluating Manager's Investments Projects Decisions (A Case Study on Jordanian Industrial Companies). International Journal of Economics and Finance, 9(12), 175. https://doi.org/10.5539/ijef.v9n12p175

Shinoda, T. (2010). Capital budgeting management practices in Japan: a focus on the use of capital budgeting methods. Economic Journal of Hokkaido University, 39, 39-50.

Taylor, P. F. D. (1994/95). ARR reinvested. Investment Analysis Journal. No. 40 Summer 1994/95.

\section{Copyrights}

Copyright for this article is retained by the author(s), with first publication rights granted to the journal.

This is an open-access article distributed under the terms and conditions of the Creative Commons Attribution license (http://creativecommons.org/licenses/by/4.0/). 